\title{
Analisis SWOT dan Media Pembelajaran di Politeknik dalam Masa Covid-19
}

\author{
Iis Mariam \\ Program Studi Administrasi Bisnis Terapan Politeknik Negeri Jakarta \\ Jl. Prof. DR. G.A. Siwabessy, Kampus Universitas Indonesia, Depok, Indonesia \\ iis.mariam@bisnis.pnj.ac.id \\ Nidia Sofa \\ Program Studi Administrasi Bisnis Terapan Politeknik Negeri Jakarta \\ Jl. Prof. DR. G.A. Siwabessy, Kampus Universitas Indonesia, Depok, Indonesia \\ nidia.sofa@bisnis.pnj.ac.id \\ Nining Latianingsih \\ Program Studi Administrasi Bisnis Terapan Politeknik Negeri Jakarta \\ Jl. Prof. DR. G.A. Siwabessy, Kampus Universitas Indonesia, Depok, Indonesia \\ nining.latianingsih@bisnis.pnj.ac.id

\section{Endah Wartiningsih} \\ Program Studi Administrasi Bisnis Politeknik Negeri Jakarta \\ Jl. Prof. DR. G.A. Siwabessy, Kampus Universitas Indonesia, Depok, Indonesia \\ endah.wartiningsih@bisnis.pnj.ac.id
}

Diterima: 01-09-2020

Disetujui: 28-12-2020

Dipublikasi: 30-01-2021

\begin{abstract}
ABSTRAK
Tujuan dari penelitian ini adalah ingin mengetahui dan menganalisis bagaimana media pembelajaran yang digunakan dalam masa Covid-19 pada politeknik menggunakan pendekatan analisis SWOT. Masalah yang terjadi selama Covid-19 dalam proses pembelajaran adalah belum adanya aturan/pedoman tentang pemilihan media pembelajaran serta strategi organisasi yg tepat untuk membantu pembelajar lebih mudah memahami materi yang dipelajari. Unit analisis dalam penelitian ini adalah mahasiswa jurusan Administrasi Niaga-PNJ, pemilihan sampel menggunakan random sampling, teknik pengumpulan data menggunakan studi literatur, observasi dan angket. Metode yang digunakan dalam penelitian ini adalah dengan pendekatan deskriptif kualitatif. Hasil penelitian menunjukkan bahwa media pembelajaran yang digunakan adalah Zoom Meeting,elearning dan WhatsApp, dan belum adanya aturan yang dapat dijadikan pedoman mengenai model yang ditetapkan di PNJ untuk digunakan dalam proses pembelajaran jarak jauh. Hasil analisis SWOT untuk kekuatan dari strategi organisasi untuk mendukung pembelajaran adalah, $(\mathbf{S})$ : pengeluaran biaya transportasi lebih hemat, lebih mudah mengatur pengelolaan waktu, memiliki waktu yang banyak untuk mengerjakan tugas kampus, akses belajar dapat dilakukan dari mana saja, motivasi belajar bertambah, lebih rileks dan nyaman dalam proses pembelajaran, penyelesaian tugas dari dosen memiliki waktu yang cukup, dekat dengan lebih termotivasi, memiliki planning work sendiri, (W): munculnya rasa malas, kesulitan mempelajari matkul praktek dan hitungan, jaringan internet tidak stabil, biaya untuk paket internet bertambah, tidak semua dosen memakai Zoom Meeting atau Google Classroom, PBM tidak komunikatif,, suasana berbeda ketika presentasi memakai daring, (O) ketika diberikan tugas untuk mencari artikel lain dari open source lebih mudah, dapat belajar materi lebih banyak, hidup lebih sehat, tidak stress, lebih sabar dan bahagia belajar diantara keluarga, terbiasa belajar daring, terbiasa dengan teknologi informasi, (T) perlu waktu untuk disiplin belajar dalam era new normal, dosen harus lebih kreatif dalam menyampaikan materi, penguasaan teknologi informasi mutlak diperlukan.
\end{abstract}

Kata Kunci:

Strategi dan media pembelajaran, pembelajaran jarak jauh, analisis SWOT 


\begin{abstract}
The purpose of this study is to find out and analyze how the media and learning strategies carried out in the Covid-19 period of polytechnics using the SWOT analysis approach. The problem that occurs during Covid-19 in the learning process is not provided regulation about distance learnin, the selection of appropriate learning media and strategy to help learners more easily understand the material being studied.The unit of analysis in this study is students in Business Administration-PNJ, sample selection using random sampling, data collection techniques using literature studies, observations and questionnaires. The method used in this research is a qualitative descriptive. The results showed that the learning media used were zoom meetings, e-learning and WhatsApp, and there were no rules that could be used as guidelines regarding the model set at PNJ for use in the distance learning proces. The results of this research used SWOT analysis for learning strategy are: $(S)$ : transportation costs are more efficient, easier to manage time management, have a lot of time to do campus work, access to learning can be done from anywhere, learning motivation increases, more relaxed and comfortable in the learning process, completing assignments from lecturers have enough tim, more motivated, have their own planning work, increase, $(W)$ : not all lecturers use the zoom meeting or google classroom, learning process is not communicative, learning situation more different when the presentation uses online, $(O)$ have learn more material from open source, live more healthy, no stress, more patient and happy learning arround the families, accustomed to online learning, accustomed to with information technology, (T) it takes time for discipline learning in the new normal era, lecturers must be more creative in teaching and learning, mastering of uisng information technology.
\end{abstract}

Keywords:

Media and learning strategies, distance learning, SWOT analysis 


\section{PENDAHULUAN}

Fenomena pendidikan tinggi pada saat terjadinya pandemi Covid-19 di Indonesia mewarnai perubahan system dan pola pembelajaran yang dimulai pada pertengahan Maret 2020 menyebabkan terjadinya perubahan sistem dan budaya belajar tidak hanya pada tingkat pendidikan dasar tetapi juga pendidikan tinggi. Politeknik sebagai salah satu penyelenggara pendidikan tinggi vokasi di Indonesia melakukan perubahan pada pola belajar mengajar, sehingga mahasiswa dan dosen tidak lagi dapat belajar secara reguler di kelas tatap muka akan tetapi berubah menjadi pendidikan jarak jauh, memakai e-learning, Zoom Meeting, Google Classroom dan sistem pendidikan berbasis teknologi lainnya.

Dalam kurun lebih dari empat bulan sejak Maret 2020 sampai bulan Juli, pola pembelajaran berubah dengan memanfaatkan sistem teknologi informasi dalam proses belajar mengajar. Masalah yang muncul adalah belum adanya ketetapan media pembelajaran yang digunakan dalam pembelajaran jarak jauh (PJJ), ketidaksiapan dari pihak mahasiswa sebagai pembelajar (learner), dosen sebagai pengajar (co-learner) dilihat dari perspekstif pola pembelajaran student center, pihak penyelenggara pendidikan (politeknik), staf tenaga kependidikan serta kesiapan sarana dan prasarana berbasis teknologi informasi. Dalam dua minggu pertama pembelajaran masih menggunakan e-learning, Google Classroom tidak hanya mahasiswa yang mengalami kesulitan tetapi juga dosen dalam memberikan materi pengajaran.

Masalah lainnya adalah belum adanya aturan/pedoman pembelajaran jarak jauh yang digunakan sebagai aturan serta mekanisme pembelajaran di Politeknik sehingga harus dibuat suatu analisis strategi untuk memetakan kekuatan dan kelemahan dalam proses pembelajaran jarak jauh. Merujuk pada masalah serta kondisi Covid-19 saat ini apabila dihubungkan dengan strategi dan media pembelajaran di politeknik dalam masa Covid-19 memiliki tujuan penelitian,

yaitu:

(1) menganalisis media pembelajaran jarak jauh menggunakan Zoom Meeting, Google Classroom, dan e-learning di Politeknik, (2) menganalisis strategi pembelajaran menggunakan analisis SWOT, (3) faktor apa yang menjadi kekuatan dan kelemahan dari pembelajaran jarak jauh di Politeknik.

\section{TINJAUAN TEORI}

Eksistensi kampus yang selama ini menjadi tempat berkumpulnya kaum akademisi untuk melakukan Tri Dharma perguruan tinggi sudah harus berubah seiring perubahan lingkungan eksternal kampus. Merujuk pada pernyataan Mendikbud Nadiem Makarim (2020) 
dalam peluncuran kebijakan merdeka belajar menyampaikan bahwa lahirnya istilah kampus merdeka merupakan proses belajar mengajar dalam kampus tidak lagi harus selamanya di kampus untuk masing-masing program studi dengan dibuatnya aturan magang tiga semester. (Kemendikbud.go.id, diakses 24 Januari 2020). Dalam kebijakan merdeka belajar untuk perguruan tinggi ada empat hal penting yang harus dicermati, yaitu: (a) otonomi perguruan tinggi negeri (PTN) dan swasta (PTS) untuk melakukan pembukaan atau pendidian program studi yang baru. Otonomi ini diberikan kepada PTN dan PTS yang memiliki akreditasi institusi $\mathrm{A}$ dan $\mathrm{B}$, dan pengecualian hanya berlaku untuk program studi kesehatan dan pendidikan, (b) adanya program re-akreditasi yang secara otomatis dilakukan untuk pemeringkatan dan sifatnya sukarela untuk perguruan tinggi dan program studi yang sudah siap untuk naik peringkat akreditasinya, (c) adanya kebebasan bagi PTN Badan Layanan Umum dan Satuan Kerja untuk menjadi PTN Badan Hukum dan Kemendikbud akan memberikan kemudahan bagi persyaratan PTN BLU dan Satker untuk menjadi PTN BH tanpa terkait dengan peringkat status akreditasi, dan (d) akan memberikan hak kepada mahasiswa untuk dapat mengambil mata kuliah di luar program studi dan melakukan perubahan definisi dari satuan kredit semester (SKS). Adapun kondisi saat ini pada perguruan tinggi termasuk politeknik adalah terjadinya gap antara kampus dengan industri karena keduanya berada pada zona masing-masing yang tidak banyak melakukan kolaborasi untuk tri dharma perguruan tinggi (Nizam, 2020).

Kampus dengan paradigma lama menjelaskan bahwa dosen lebih banyak mengajar di luar meneliti dan melakukan pengabdian kepada masyarakat, hasil penelitian tidak berorientasi pada kebutuhan industri, merumuskan capaian pembelajaran yang tidak tepat. Sedangkan dari pihak industri hasil karya riset dari kampus (dosen dan mahasiswa) belum memenuhi kebutuhan industri dan penelitian fokus pada akademik belum bisa menghasilkan produk yang bernilai ekonomis dan dapat diproduksi secara masal. Untuk menganalisis bagaimana konsep kampus merdeka dilaksanakan dan strategi pembelajaran di era Covid-19 saat ini masuk pada era new normal, membutuhkan informasi dan kajian yang dilakukan dengan memetakan faktor kekuatan, kelemahan, kesempatan serta peluang kampus melalui analisis SWOT yang pada akhirnya kampus dapat menghasilkan sumber daya manusia yang unggul, kompeten dan berdaya saing tinggi di industri. Berdasarkan konsep lulusan Politeknik yang harus adaptif dan kompeten agar mampu bekerja di industri maka diperlukan suatu strategi. Strategi dalam organisasi pembelajar (learning organization) merupakan suatu hal yang penting untuk dipersiapkan agar organisasi berkembang dan tumbuh menjadi organisasi yang mampu memenangkan persaingan. Dalam pemikiran David (2011) bahwa 
strategi merupakan suatu sarana yang harus dicapai secara bersama dan dinyatakan dalam bentuk perencanaan jangka panjang organisasi. Strategi dipandang sebagai suatu aksi yang potensial dan membutuhkan tindakan keputusan dari manajemen puncak dan sumber daya perusahaan dalam jumlah yang besar.

Strategi di dalam organisasi pembelajar juga tumbuh dan memiliki daya saing agar mampu memenangkan persaingan dan organisasi dapat melakukan evaluasi dengan mempertimbangkan faktor SWOT (kekuatan, kelemahan, kesempatan dan ancaman). SWOT menjadi pola kerangka kerja organisasi untuk bekerja dengan mempertimbangkan faktor internal maupun faktor eksternal organisasi (Kotler \& Keller, 2009; Lumpkin \& Dess, 2006; Rangkuti, 2008; Wignaraja, 2005). Dalam konsep pembelajaran dikenal adanya strategi yang menjadi cara bagaimana proses pembelajaran dilakukan antara pembelajar (learner) dengan dosen (co-learner) sehingga dapat diciptakan pola pembelajaran yang menyenangkan, kreatif dan inovatif. Strategi diperlukan di dalam pembelajaran sebagai upaya yang dilakukan secara sistematis untuk mengkomunikasikan materi pembelajaran kepeda pembelajar agar tujuan pembelajaran dapat tercapai. Strategi dapat diartikan sebagai perencanaan, metoden atau pelayanan dari kegiatan yang telah dirancang untuk mencapai tujuan pendididikan (David dalam Sanjaya, 2007). Pengertian strategi pembelajaran memberikan gambaran bahwa strategi diperlukan di dalam pembelajaran sebagai suatu rencana tindakan dalam pemakaian metode dan pemanfaatan berbagai strategi yang baru sampai kepada proses bagaimana penyusunan rencana kerja dipersiapkan, serta disusun untuk mencapai tujuan pendidikan. Sedangkan Kemp dalam Sanjaya (2007) menjelaskan bahwa strategi pembelajaran merupakan kegiatan pembelajaran yang seharusnya dikerjakan oleh pengajar kepada pembelajar agar tujuan pembelajaran dapat dicapai secara efektif dan efisien. Menurut Bennett \& Bloom (1979) mengenai konsep model pencapaian pembelajaran ada empat faktor yaitu: pengetahuan yang dimiliki siswa, tingkat motivasi, lamanya waktu proses pembelajaran serta kualitas dari instruksi yang diberikan. Adapun tingkatan dalam proses pembelajaran adanya hubungan dan pengalaman yang dimiliki, observasi, imaginasi, transfer pengetahuan, latihan, penambahan, penyempurnaan dan penampilan. Tóth (2012) menyampaikan konsep strategi pembelajaran pada saat ini berorientasi pada student center. Pengajar melakukan pemilihan dalam metode mengajar dan metode pembelajaran, termasuk ketersediaan sarana dan bentuk yang paling sesuai untuk memproses silabus pengjaran kepada pembelajar. Menurut Sakarinto, 2020) pembelajaran pendidikan vokasi dalam masa Covid-19 saat ini menerapkan sistem pembelajaran $60 \%$ praktik dan $40 \%$ teori dan diharuskan untuk melakukan perubahan dalam strategi pembelajaran seperti pembelajaran 
mata kuliah praktik diubah menjadi simulasi. Sedangkan untuk mata kuliah yang tetap mengharuskan praktik nyata dipindahkan ke semester akhir selama pandemik. Kondisi pandemik ini memberikan implikasi bahwa kekosongan pada jam mata kuliah praktik diganti dengan mata kuliah berbasis teori yang lebih mudah diterapkan dalam pembelajaran jarak jauh (PJJ). Nizam (2020) mengatakan bahwa dalam masa pandemik Covid-19 proses pembelajaran di kampus telah berubah secara revolusioner dimana dalam waktu yang sangat pendek, kampus dipkasa untuk melakukan pembelajaran secara daring. Saat ini telah 97\% perguruan tinggi telah mengadopsi pembelajaran daring, melakukan kerjasama dengan provider komunikasi untuk memberikan akses gratis mahasiswa ke platform pembelajaran daring, lamat URL kampus didaftarkan masuk sebagai white list sehingga mahasiswa tidak dikenakan biaya saat mengakses URL tersebut. SWOT (strength, weaknessm opportunity dan treatment) merupakan keseluruhan evaluasi mengenai kekuatan, kelemahan, peluang dan ancaman perusahaan (Kotler \& Keller, 2009). Analisis SWOT merupakan identifikasi berbagai faktor secara sistematis untuk merumuskan strategi perusahaan (Rangkuti, 2008).

\section{METODE RISET}

Metode yang digunakan dalam penelitian adalah deskriptif kualitatif merujuk pada Sugiyono, (2016). Adapun teknik pengumpulan data menggunakan kuesioner dengan skala Likert (1-4) yang diberikan bobot pada setiap pernyataan, pendistribusian kuesioner menggunakan google form, studi literatur tentang kurikulum yang digunakan di jurusan Administrasi Niaga, media pembelajaran yang digunakan pada proses belajar mengajar, partisipative observation mengenai proses pembelajaran yang dilakukan secara daring pada saat pembelajaran jarak jauh (PJJ) selama masa pandemik Covid-19.

Unit analisisnya adalah mahasiswa jurusan Administrasi Niaga-Politeknik Negeri Jakarta (PNJ) yang ada di semester dua dan empat sebagai responden. Pemilihan sampel dilakukan menggunakan nonprobability sampling dengan teknik sampling purposive (Sugiyono, 2016), sedangkan jumlah kuesioner yang berhasil terkumpul kembali sebanyak 196 buah.

\section{HASIL PENELITIAN DAN PEMBAHASAN}

Penelitian dilakukan di PNJ dengan unit analisisnya adalah mahasiswa semester dua dan empat pada jurusan Administrasi Niaga dan berasal dari tiga program studi (D3 Administrasi Bisnis, D4 Administrasi Bisnis Terapan, D4 MICE), Adapun pemilihan sampel 
menggunakan nonprobability sampling (Sugiyono, 2016). Teknik pengumpulan data dilakukan menggunakan kuesioner yang mencakup dua dimensi, yaitu dimensi Strategi pembelajaran serta media pembelajaran yang selanjutnya akan dianalisis menggunakan SWOT analisis. Kuesioner yang terkumpul sebanyak 196 buah berasal dari mahasiswa D3 Administrasi Bisnis, D4 Administrasi Bisnis Terapan, dan D4 MICE.

Kuesioner merujuk pada skala Likert (Sangat Setuju, Setuju, Tidak Setuju dan Sangat Tidak Setuju). Wawancara dilakukan dengan Ketua Program Studi dan Ketua Jurusan Administrasi Niaga dimana masing-masing berperan penting di dalam memberikan arahan kebijakan dan keputusan penyelenggaraan pemebelajaran jarak jauh (PJJ) dengan tetap merujuk pada kebijakan dari Direktur PNJ mengenai penyelenggaraan PJJ pada saat pandemik Covid-19.

Tabel 1. Faktor Internal dan Faktor Eksternal

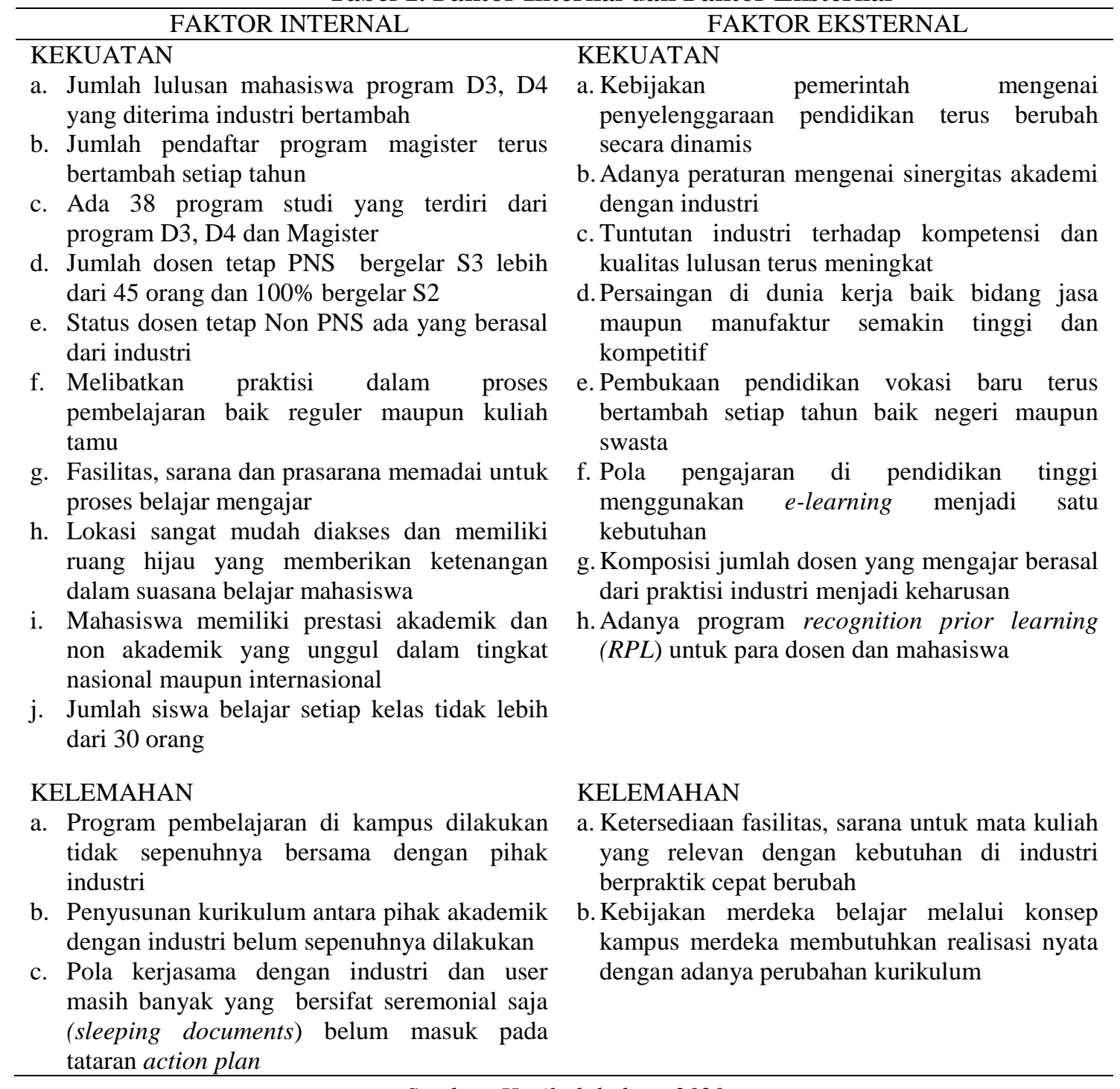


Berdasarkan Tabel 1. yang menjelaskan data mengenai identifikasi faktor strategi internal dan strategi eksternal dalam strategi PJJ-PNJ. Selanjutnya dijelaskan pada Tabel 2 mengenai analisis SWOT bagaimana strategi pembelajaran jarak jauh dilakukan pada saat pandemik Covid-19.

Tabel 2. Analisis SWOT dalam PJJ

STRENGHT WEAKNESS

a. Menghemat biaya transportasi ke kampus

a. Fasilitas internet terkadang tidak stabil

b. Efisiensi waktu

c. Memiliki time managemen yang baik

d. Memiliki waktu dan kesempatan mengerjakan tugas lainnya

e. Suasana belajar menjadi lebih rileks

f. Mengurangi rasa stress di perjalanan dari dan ke kampus

g. Belajar dapat dilakukan dimana saja tanpa terpaku dengan ruang kelas

h. Motivasi dan support dari orang tua/teman kos lebih banyak manfaatnya

i. Waktu pengerjaan tugas/quiz dari dosen diberikan tidak terburu-buru

j. Lebih produktif di luar belajar formal juga dapat berbisnis (strat up melalui daring).

\section{OPPORTUNITY}

a. Lebih mudah untuk mencari sumber informasi yang relevan dengan mata kuliah

b. Dapat melakukan pekerjaan rumah dan membantu kegiatan orang tua setelah selesai belajar

c. Mengakses informasi lebih banyak melalui media virtual lainnya (zoom meeting, google classroom, e-learning)

d. Terbiasa dengan konsep belajar secara online (zoom meeting, google classroom, e-learning)

e. Lebih menghargai pemanfaatan waktu dengan efektif dan efisien

f. Produktivitas dan motivasi belajar secara mandiri. b. Adanya penambahan alokasi anggaran untuk membeli quota/paket internet pada awal PJJ

c. Terkadang tidak disiplin waktu belajar karena ada gangguan di dalam rumah

d. Tugas dari dosen secara bersamaan membutuhkan time management yang baik

e. Jika ada topic materi kuliah yang tidak dimengerti menjadi masalah karena tidak dapat bertanya langsung (dosen tidak menggunakan zoom meeting atau video melalui google classroom, e-learning)

f. Jika ada tugas kelompok agak sulit berkomunikasi dan diskusi dengan tim untuk dikerjakan secara berkelompok

g. Mata kuliah yang topiknya banyak hitungan atau praktik tidak mudah dimengerti

h. Kuota internet cepat habis jika menggunakan video

i. Karena suasana belajar di rumah terkadang timbul rasa malas.

\section{THREATS}

a. Kompetensi yang dituntut dunia kerja lebih tinggi

b. Pengalaman belajar dan memecahkan masalah sendiri menjadi penting

c. Penguasaan terhadap teknologi informasi menjadi suatu keharusan

d. Pekerjaan tertentu dapat dilakukan secara virtual tanpa harus tatap muka

e. Soft skill yang unggul dari mahasiswa menjadi kompetensi lain yang wajib dimiliki

f. Mahasiswa yang kreatif dan inovatif yang dicari dunia kerja

g. Kemampuan berkomunikasi dan disiplin dalam bekerja menjadi nilai penting

Sumber: Hasil olah data, 2020

Dari Tabel 2 di atas maka perlu dibuat suatu analisis strategi organisasi yang dilakukan terhadap faktor internal dan eksternal strategi untuk penyelenggaraan pembelajaran pada masa Covid-19 dan dapat dilihat pada Tabel 3 sebagai berikut: 
Tabel 3. Analisis SWOT Strategi untuk Pembelajaran Jarak Jauh

Faktor

Internal
Kekuatan (Strengths)

S1 Hemat biaya dan waktu

S2 Time management yang baik

S3 Suasana belajar lebih rileks

S4 Berkurangnya rasa stress ketika belajar

S5 Motivasi belajar bertambah

S6 Lebih produktif, kreatif dan inovatif dalam belajar.
Faktor

Eksternal

\section{Peluang (Opportunities)}

O1: Lebih mudah mencari sumber informasi (Zoom Meeting, Google Classroom, e-learning email dan WhatsApp Group), )

O2: Dapat melakukan pekerjaan rumah setelah selesai waktu belajar

O3: Mengaskes informasi lebih banyak dari media virtual lainnya

O4 Terbiasa dengan konsep media belajar secara online (Zoom Meeting, Google Classroom, elearning, e-mail dan WhatsApp Group)

O5 Lebih menghargai pemanfaatan waktu dengan efektif dan efisien

O6 Produktivitas dan motivasi belajar secara mandiri.

\begin{tabular}{l} 
Ancaman (Treats) \\
\hline T1 Kompetensi yang dituntut dunia
\end{tabular}
kerja lebih tinggi

T2 Pengalaman belajar dan memecahkan masalah sendiri menjadi penting

T3 Penguasaan terhadap teknologi informasi menjadi suatu keharusan

T4 Pekerjaan tertentu dapat dilakukan secara virtual tanpa harus tatap muka

T5 Soft skill yang unggul dari mahasiswa menjadi kompetensi lain yang wajib dimiliki

T6 Mahasiswa yang kreatif dan inovatif yang dicari dunia kerja

T7 Kemampuan berkomunikasi dan disiplin dalam bekerja menjadi nilai penting

\section{Kelemahan (Weakness)}

W1 Penambahan biaya untuk membeli paket internet

W2 Terkadang muncul rasa malas karena belajar lebih rileks

W3 Tidak disiplin belajar karena berada di rumah/kost

W4 Tidak dapat berdiskusi langsung dengan teman ketika ada tugas kelompok

W5 Suasana belajar menjadi berbeda

W6 Materi tidak mudah dimengerti karena metode pembelajaran dari dosen yang berbeda,

S-0 Strategies

a. Sumber informasi untuk rujukan mata kuliah diberikan lebih banyak (S1, S2, O1, O3, O6)

b. Time management digunakan secara maksimal ( S2, S6, O4, O5)

c. Produktivitas dan motivasi belajar lebih ditingkatkan (S4, S5, S6, O5, O6).

\section{W-O Strategies}

a.Memilih harga paket internet yang terjangkau (W1, W2, O2, O3)

b. Lingkungan belajar dibuat menyenangkan (W3, W4, W5, O4, O5)

c.Materi dibuat dalam PPT yang mudah dimengerti (W4, W6, O5, O6).

\section{S-T Strategies}

a. Membangun mempertahankan akreditasi institusi saat ini (S1, S2, $\mathrm{T} 1, \mathrm{~T} 2)$

b. Meningkatkan komunikasi yang baik antara orangtua dan peran pembimbing akademik (S2, S5, T2, T5)

c. Meningkatkan kompetensi dan profesionalisme tidak saja dosen tetapi juga mahasiswa (S1, S2, T3, T4, T5)

d. Memberikan pendampingan dan arahan untuk mahasiswa yang kreatif dan inovatif untuk belajar lebih strategis (S5, S6, T6, T7).

\section{W-T Strategies}

a.Menekan pengeluaran biaya untuk paket internet untuk pembelajaran jarak jauh kuliah (W1, T3)

b. Institusi memberikan tambahan quota/paket internet bagi mahasiswa (W1. W2, T2. T3, T4)

\section{c. Memberikan}

pengalaman belajar seperti di industri dengan tugas yang dikerjakan tepat waktu (Memantau trend lulusan yang diminati industry (W3, W4, W5, W6, T4, T5, T6). 
Dari analisis matrik yang telah dilakukan dengan matrik IE dan SWOT maka strategi untuk pembelajaran jarak jauh selama pandemic Covid-19 dilakukan dalam emapat faktor besar, yaitu: membangun image kombinasi antara (S1, S2, T1, T2) hal ini sejalan dengan implikasi teoritis bahwa dalam strategi diperlukan suatu perencanaan dan tahapan pelaksanaan yang tepat (David, 2011). .Untuk meningkatkan kompetensi mahasiswa adalah kombinasi antara (S1, S2, T3, T4, T5) dan hal ini sejalan dengan konsep merdeka belajar dimana mahasiswa diberikan kesempatan untuk belajar tidak hanya di kampus tetapi di luar kampus seperti melakukan magang, mengerjakan suatu proyek yang hasil dari kegiatan tersebut dikonversi menjadi bagian dari SKS (konsep kampus merdeka-Mendikbud, 2020), Dalam hal peningkatan komunikasi yang baik antara orangtua dan peran pembimbing akademik (S2, S5, T2, T5) ini merupakan implementasi dari konsep kampus merdeka dan strategi belajar (Pusriawan \& Soenarto, 2019; Sanjaya, 2007). Sedangkan untuk kegiatan melakukan pendampingan dan arahan untuk mahasiswa yang kreatif dan inovatif untuk belajar lebih strategis (S5, S6, T6, T7) merupakan bentuk strategi dalam pembelajaran yang diharapkan berhasil diwujudkan dengan menghasilkan pembelajar yang disiplin, kreatif, inovatif dan mandiri. Media yang digunakan dalam proses PJJ oleh dosen kepada mahasiswa adalah media Google Classroom, Zoom Meeting, e-mail dan WhatsApp Group untuk diskusi. Hasilnya bahwa Google Classroom, Zoom Meeting dipilih lebih komunikatif walaupun membutuhkan internet yang besar. Dari media pembelajaran ini memberikan gambaran bahwa e-learning tidak mengurangi tujuan dari rencana strategis dari pendidikan tinggi serta PNJ untuk menghasilkan lulusan yang berdaya saing tinggi dan kompeten. Temuan lainnya belum aturan yang mengatur PJJ baru dalam bentuk surat edaran dan belum ada buku pedoman mengenai proses PJJ yang disampaikan kepada dosen dan mahasiswa. SWOT analisis digunakan dalam memetakan dan mengevaluasi bagaimana PJJ dilaksanakan agar dapat mencapai tujuan mata kuliah yang sesuai dengan rencana pembelajaran semester (RPS). Hasil dari matrik SWOT diperoleh kekuatan dari pemodelan PJJ menghasilkan enam kekuatan, yaitu: efisiensi biaya dan waktu, time management yang baik, suasana belajar lebih rileks, berkurangnya rasa stress ketika belajar, motivasi belajar bertambah serta lebih produktif, kreatif dan inovatif dalam belajar. Sedangkan kelemahan dari PJJ ini ada enam faktor, yaitu: adanya penambahan biaya untuk membeli paket internet, terkadang muncul rasa malas karena belajar lebih rileks, tidak disiplin belajar karena berada di rumah/kost, tidak dapat berdiskusi langsung dengan teman atau dosen ketika ada tugas kelompok, suasana belajar menjadi berbeda, dan materi tidak mudah dimengerti karena metode pembelajaran dari dosen yang berbeda. Hasil penelitian menjelaskan bahwa dalam proses pembelajaran 
jarak jauh ada tiga media yang digunakan, yaitu: Zoom Meeting. e-learning dan WhatsApp. Sedangkan aturan/pedoman yang mengatur proses pembelajaran jarak jauh belum ada untuk semester genap tahun ajaran 2019/2020, sehingga media pembelajaran yang dipilih dosen dapat menggunakan salah satu dari tiga media (Zoom Meeting, e-learning dan WhatsApp).

\section{KESIMPULAN DAN SARAN}

Kesimpulan dari penelitian ini antara lain, media pembelajaran yang digunakan selama Covid-19 di PNJ adalah Zoom Meeting, e-learning dan WhatsApp Group; analisis SWOT digunakan untuk mengevaluasi pelaksanaan pembelajaran jarak jauh dilihat dari perspektif organisasi PNJ mengenai materi kuliah yang disampaikan harus sesuai dengan rencana pembelajaran semester (RPS); implikasi praktis dihasilkannya masing-masing enam unsur kekuatan dan kelemahan dalam PJJ berbasis problem based learning yang harus direkonstruksi kembali pada proses pembelajaran ketika menggunakan media pembelajaran online/daring.

Saran dari penelitian ini antara lain dibuatnya buku pedoman pembelajaran jarak jauh dari PNJ untuk pedoman dosen dan mahasiswa agar mengetahui dan mengimplementasikan hak dan kewajiban kedua belah pihak terkait strategi dan media pembelajaran yang digunakan; untuk mendapatkan hasil strategi PJJ yang kreatif dan inovatif, perlu ditingkatkannya fasilitas bandwitch internet PNJ untuk dosen dan mahasiswa dalam proses belajar mengajar; tetap dibangun suasana belajar yang menyenangkan (fun learning) agar mahasiswa tetap termotivasi dan disiplin belajar walaupun dilakukan di rumah. 


\section{DAFTAR PUSTAKA}

Bennett, N., \& Bloom, B. S. (1979). Human Characteristics and School Learning. British Journal of Educational Studies, 284. https://doi.org/10.2307/3119887

David, F. R. (2011). Konsep Manajemen Strategis. Acta Universitatis Agriculturae et Silviculturae Mendelianae Brunensis. Jakarta: Salemba Empat.

Kotler, P., \& Keller, K. L. (2009). Marketing Management (13th ed.). New Jersey: Prentice Hall.

Lumpkin, G. T., \& Dess, G. G. (2006). The effect of "simplicity" on the strategyperformance relationship: A note. Journal of Management Studies. https://doi.org/10.1111/j.1467-6486.2006.00652.x

Nizam. (2020). Pendidikan Vokasi Ubah Strategi Pembelajaran. Retrieved from https://www.beritasatu.com/nasional/638949-selama-pandemi-pendidikan-vokasi-ubahstrategi-pembelajaran

Pusriawan, P., \& Soenarto, S. (2019). Employability skills of vocational school students in Palu City for entering the work world. Jurnal Pendidikan Vokasi, 9(1), 33-42. https://doi.org/10.21831/jpv.v9i1.23351

Rangkuti. (2008). Analisis SWOT-Teknik Membedah Kasus Bisnis. Jakarta: PT. Gramedia Pustaka Utama.

Sakarinto, W. (2020). Pendidikan Vokasi Ubah Strategi Pembelajaran. Retrieved from https://www.beritasatu.com/nasional/638949-selama-pandemi-pendidikan-vokasi-ubahstrategi-pembelajaran

Sanjaya, W. (2007). Strategi Pembelajaran Berorientasi Standar Proses Pendidikan. Jakarta: Kencana Prenada Media Group.

Sugiyono, P. D. (2016). Metode Penelitian Kuantitatif, Kualitatif, dan R\&D. Alfabeta. Bandung.

Tóth, P. (2012). Learning Strategies and Styles in Vocational Education. Acta Polytechnica Hungarica, 9(3).

Wignaraja, G. (2005). Competitiveness Strategy in Developing Countries: A Manual for Policy Analysis. Competitiveness Strategy in Developing Countries. Abingdon: Routledge. https://doi.org/10.4324/9780203466032. 